\title{
PENINGKATAN PENGETAHUAN DAN KETRAMPILAN MEMBUAT WEDANG JAHE SERAI UNTUK PENGUATAN IMUNITAS MENCEGAH COVID-19 DI DESA PANGKALAN JATI CINERE DEPOK
}

\author{
IMPROVING KONWLEDGE AND SKILL OF MAKING GINGER \\ LEMONGRASS WATER FOR IMMUNITY BOOSTER TO PREVENT \\ COVID-19 IN PANGKALAN JATI CINERE DEPOK
}

\author{
Yuni Setyaningsih" ${ }^{1)}$, Tiwuk Susantiningsih ${ }^{2)}$, Agneta Irmarahayu ${ }^{3)}$, Fajriati Zulfa $^{4)}$ \\ ${ }^{1,2,3,4}$ Fakultas Kedokteran Universitas Pembangunan Nasional Veteran Jakarta \\ ${ }^{1}$ Email: yunisetyaningsih@upnvj.ac.id
}

\begin{abstract}
Abstrak: Covid-19 adalah penyakit menular disebabkan SARS-CoV-2 yang telah menyebar menjadi pandemi di seluruh dunia termasuk Indonesia. Covid-19 dapat berupa penyakit ringan atau sampai kematian dan obat untuk Covid-19 belum ada. Indonesia merupakan negara yang kaya akan tanaman herbal, yang sudah banyak digunakan di masyarakat. Dua tanaman herbal yang sering digunakan adalah jahe dan serai. Berdasarkan penelitian tanaman ini dapat memelihara kesehatan dan meningkatkan sistem imun. Tujuan pengabdian masyarakat ini adalah untuk memberikan pengetahuan tentang manfaat jahe serai dan keterampilan membuat wedang jahe serai dalam rangka peningkatan sistem imun pada masa pandemi Covid-19. Metode yang digunakan adalah penyuluhan dan demonstrasi pembuatan wedang jahe serai serta mengikutsertakan responden untuk berpartisipasi aktif dalam pembuatan wedang jahe serai. Pada pengabdian masyarakat ini didapatkan hasil adanya peningkatan pengetahuan responden mengenai manfaat wedang jahe serai dan cara pembuatannya. Diharapkan setelah pengabdian masyarakat ini responden dapat menerapkan dan mengaplikaskan pengetahuan yang didapatkan dalam rangka meningkatkan sistem imun pada masa pandemi Covid-19.
\end{abstract}

Kata Kunci: Covid-19, Wedang, Jahe, Serai, Sistem imun

Abstract: Covid-19 is a disease caused by SARS-CoV-2 which had spread to become pandemic throughout the world, including Indonesia. Covid-19 could be in the form of illness or until death and there is no cure for Covid-19. Indonesia is a country that rich in herbal plants, which had been widely used in the community. Two of herbs that are often used are ginger and lemongrass. Based on research these plants could maintain health and improve the immune system. The aim of this community service is to provide knowledge about the benefits of lemongrass ginger and skills in making lemongrass ginger water to boost the immune system during the Covid-19 pandemic. The method used was counseling and demonstration of making lemongrass ginger water and involve respondents to actively participate in making of lemongrass ginger water. At this community service, it was found that there was an increase in the respondents' knowledge about the benefits of lemongrass ginger water and how to make it. It is hoped that 
INTEGRITAS : Jurnal Pengabdian

Vol 5 No 2 Desember 2021

ISSN 2580 - 7978 (cetak) ISSN 2615 - 0794 (online)

after this community service, respondents can apply the knowledge they get in order to improve the immune system during the Covid-19 pandemic.

Keywords: Covid-19, Water, Ginger, Lemongrass, Immune syste

\section{PENDAHULUAN}

Coronavirus Disease 2019 (Covid-19) adalah penyakit infeksi yang menular disebabkan SARS-CoV-2, suatu corona virus jenis baru. Kasus pertama Covid-19 dilaporkan di Kota Wuhan pada Januari 2020 dan kemudian ditetapkan sebagai pandemik oleh WHO pada bulan Maret 2020. Penyebaran Covid-19 ini berlangsung cepat dan menyebar ke berbagai negara termasuk Indonesia. Kasus pertama di Indonesia di mulai pada 2 Maret 2020 dan terus meningat dan menyebar ke seluruh wilayah Indonesia (Kemenkes RI, 2020). Menurut kementerian kesehatan jumlah tempat tidur di Rumah Sakit di Indonesia hanya 309.100 dan kebanyakan berada di pulau Jawa. Selain itu kurang dari 6000 tempat tidur di ICU di seluruh Indonesia. Indonesia hanya memiliki 2,7 tempat tidur ICU per 100.000 penduduk sehingga termasuk Negara dengan ranking yang rendah. Ditambah lagi, ventilator mekanik tidak tersedia secara luas di daerah pedesaan dan kekurangan peralatan untuk proteksi tenaga medis di awal pandemi (Setiati dan Azwar 2020).

Tanda dan gejala umum infeksi ini adalah gangguan pernafasan yang akut, seperti demam, batuk serta sesak napas, dengan masa inkubasi rata-rata 5-6 hari dan paling lama 14 hari. Pada kasus yang berat dapat terjadi pneumonia, gagal napas akut, gagal ginjal dan kematian. Menurut data dari Negara yang terkena dampak di awal pandemi, sekitar 40\% mengalami kasus ringan, 40\% kasus sedang, 15\% kasus parah dan 5\% kondisi kritis. Hingga saat ini obat spesifik untuk mencegah dan mengobati Covid-19 masih belum ada (Kemenkes RI, 2020).

Dalam rangka mencegah terjadinya Covid-19, maka diharapkan masyarakat dapat memelihara kesehatan dan meningkatkan sistem imun tubuh. Obat yang berasal dari bahan alami seperti tanaman telah banyak memperlihatkan peranannya dalam memelihara kesehatan tubuh, sehingga dapat digunakan sebagai upaya pencegahan, meningkatkan kesehatan, dan menyembuhkan penyakit (Mindarti dan Nurbaeti, 2015). 
Salah satu tanaman herbal yang sudah banyak dimanfaatkan untuk memelihara kesehatan adalah jahe yang banyak dan mudah didapatkan masyarakat (Melawati, dkk., 2010). Jahe merupakan salah satu tanaman yang sudah lama dikonsumsi masyarakat Indonesia, dan sejak akhir abad 20 sering digunakan dalam formula makanan dan minuman kesehatan. Senyawa biokatif dalam jahe diantaranya oleoresin, gingerol dan shagaol sudah banyak diteliti sebagai antbakteri, antitusif dan antioksidan, dan senyawa antioksidan telah dibuktikan dapat meningkatkan ketahanan tubuh manusia (Tejasari, dkk., 2002).

Selain jahe, serai wangi juga merupakan salah satu tanaman yang biasanya digunakan sebagai obat. Pada penelitian yang telah dilakukan serai wangi mengandung senyawa yang dapat bersifat sebagai antibakteri. Pada penelitian juga ditemukan kandungan antioksidan pada serai wangi (Hendrik, dkk, 2013). Mayarakat di desa Pangkalan Jati terdiri dari masyarakat yang beragam, diantaranya adalah ibu-ibu rumah tangga yang tegabung dalam Tim Pengajian Ibu-Ibu Pangkalan Jati yang menjadi sasaran pengabdian ini. Berdasarkan latar belakang tersebut, dalam rangka memelihara kesehatan msyarakat dan meningkatan sistem imun pada masa pandemi Covid-19, dilakukan penyuluhan dan pelatihan pembuatan wedang jahe serai pada ibu-ibu di desa Pangkalan Jati, Cinere, Depok.

\section{METODE}

Dilakukan penyuluhan mengenai cara pembuatan wedang jahe serai, dengan sebelumnya memberikan kuesioner pre test tentang Covid-19 dan wedang jahe serai kepada ibu-ibu di desa Pangkalan Jati, Cinere Depok, lima bulan setelah terjadinya Covid-19 di Indonesia. Kemudian dilakukan demonstrasi cara pembuatan wedang jahe serai serta di akhiri dengan kuesinoer posttest tentang Covid-19 dan wedang jahe serai untuk melihat apakah terdapat peningkatan pengetahuan dan keterampilan responden.

\section{HASIL DAN PEMBAHASAN}

Pada kegiatan pengabdian masyarakat ini dihadiri oleh 10 orang responden, dikarenakan masih dalam pandemi Covid-19, sehingga jumlah responden hanya 
10 agar masih bisa melakukan protokol kesehatan seperti menjaga jarak, memakai masker dan mencuci tangan menggunakan handsenitizer. Karakteristik usia responden disajikan dalam Gambar 1.

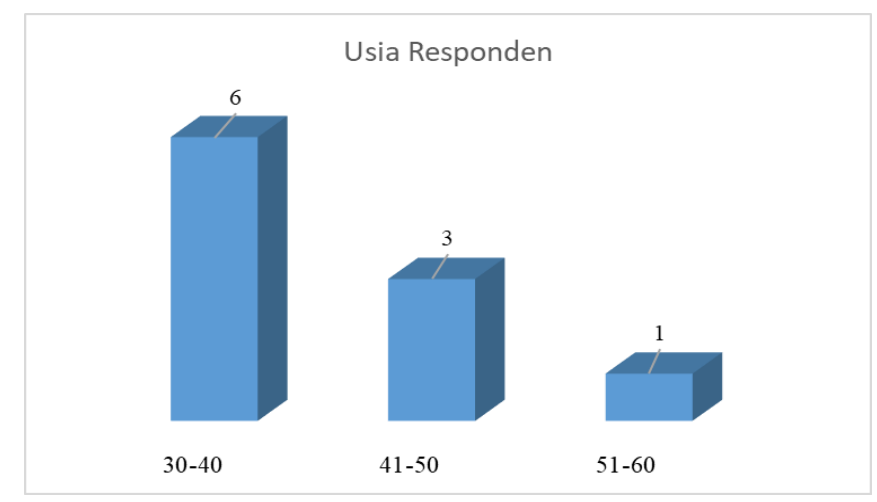

Gambar 1. Usia Responden yang Mengikuti Penyuluhan dan Peningkatan Keterampilan Pembuatan Wedang Jahe Serai

Responden pada pengabdian masyarakat ini paling banyak di usia 30-40 tahun, diikuti usia 41-50 tahun dan >50 tahun. Pada responden dengan ibu-ibu usia reproduktif diharapkan dapat menerapkan pengetahuan yang didapat untuk keluarganya dan orang-orang disekitarnya, dalam rangka memelihara kesehatan dan peningkatan sistem imun. Karakteristik pendidikan terkahir responden disajikan dalam Gambar 2.

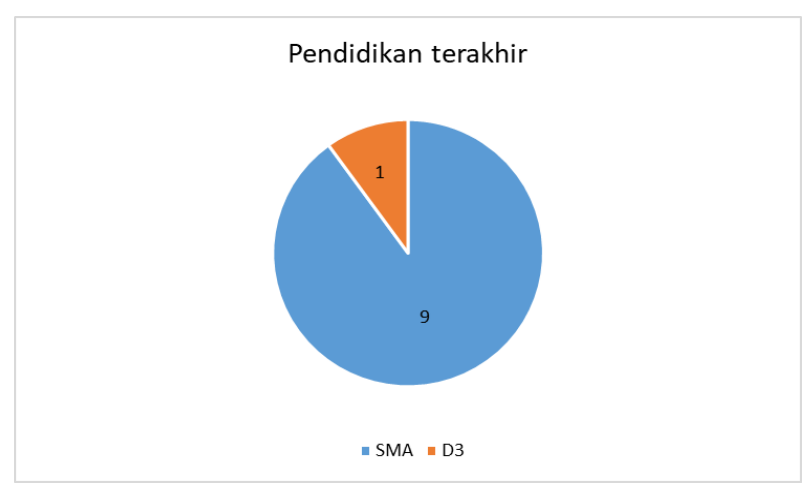

Gambar 2. Pendidikan terakhir responden yang mengikuti penyuluhan dan peningkatan keterampilan pembuatan wedang jahe serai

Pada gambar di atas terlihat bahwa pendidikan terkahir responden minimal SMA, sehingga diharapkan pemahaman responden terhadap penyuluhan dan cara pembuatan wedang jahe serai ini akan lebih baik.

Sebelum dilakukan penyuluhan dan pelatihan pembuatan wedang jahe serai ini diberikan kuesioner tentang Covid-19 dan wedang jahe serai yang diisi 
responden selama maksimal 10 menit. Setelah itu dilakukan penyuluhan mengenai Covid-19 secara singkat, dan cara pembuatan wedang jahe serai untuk memelihara kesehatan dan meningkatkan imunitas. Selama penyuluhan terlihat antusiasme responden dengan beberapa pertanyaan yang diajukan setelah penyuluhan. Setelah dilakukan penyuluhan, dilakukan pelatihan pembuatan wedang jahe serai. Bahanbahan yang diperlukan untuk pembuatan wedang jahe serai ini adalah serai, jahe, daun pandan, daun jeruk, kayu manis, gula merah dan air. Pada saat dilakukan demonstrasi cara pembuatan wedang jahe serai, responden juga terlihat antusias. Responden memperhatikan dengan seksama bagaimana cara pembuatannya, dan mencoba hasil pembuatan wedang jahe serai.

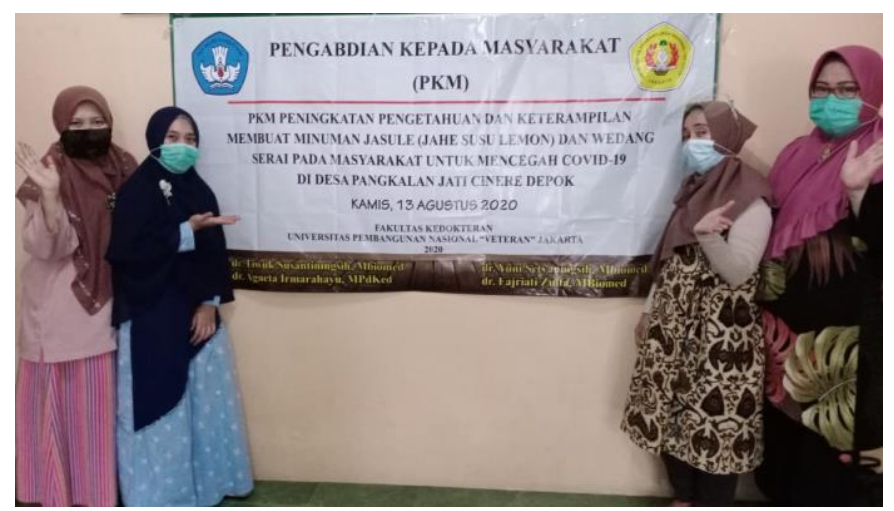

Gambar 3. Tim Pengabdian Penyuluhan dan Peningkatan Keterampilan Membuat Wedang Jahe Serai.

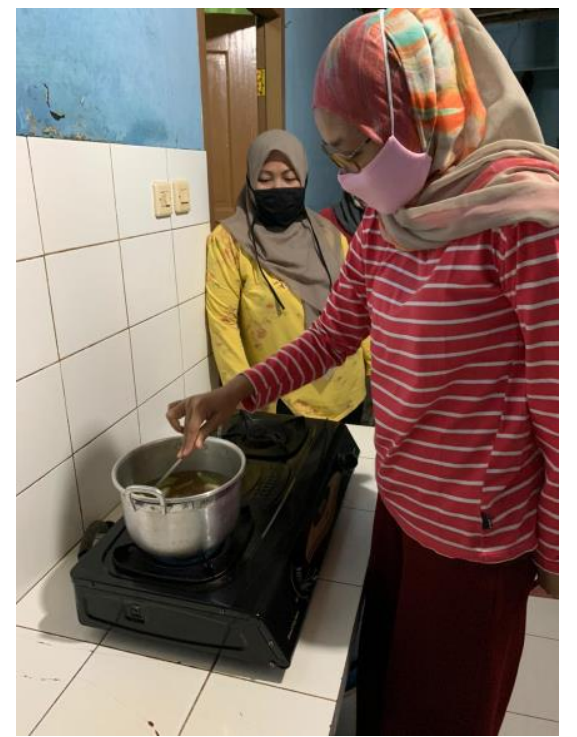

(a)

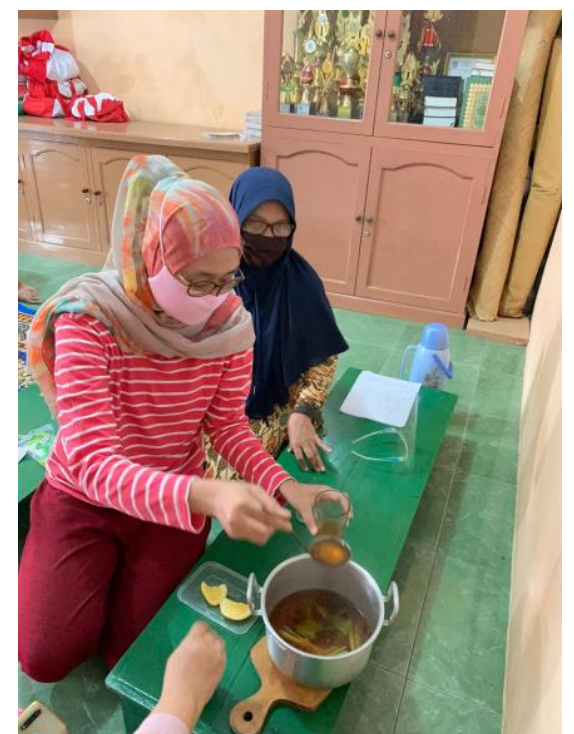

(b)

Gambar 4. (a) Responden mencoba membuat wedang jahe serai.

(c) Responden mencoba hasil pembuatan wedang jahe serai 
Pada akhir kegiatan diberikan kuesioner kembali, untuk melihat apakah terdapat peningkatan pengetahuan responden setelah penyuluhan. Hasil kuesioner pre test dan post test terlihat pada Tabel 1.

Tabel 1. Rerata Nilai Pretest dan Posttest

\begin{tabular}{lc}
\hline \multicolumn{1}{c}{ Kuesioner } & Rerata Nilai \\
\hline Pre Test & 49.13 \\
Post Test & 81.50 \\
\hline Peningkatan pengetahuan & 32.37
\end{tabular}

Dari tabel di atas terlihat bahwa pada pretest, rerata nilai responden adalah 49.13 yang berarti nilai nya masih kecil, sedangkan pada hasil posttest terdapat kenaikan nilai responden menjadi 81.5. Terdapat kenaikan 32.37 nilai daripada hasil pretest, hal ini menunjukkan terdapat peningkatan pengetahuan responden mengenai manfaat wedang jahe serai dan cara pembuatannya. Diharapkan setelah dilakukannya pengabdian masyarakat ini responden dapat menerapkan pengetahuan yang telah dimilikinya tentang wedang jahe serai dan mengaplikasikannya dalam kehidupan sehari-hari di masa pandemi ini, supaya terpelihara kesehatannya dan meningkat imunitasnya. Walaupun demikian dalam masa pandemi responden juga tetap harus melakukan protokol kesehatan untuk mencegah terjadinya Covid-19.

\section{KESIMPULAN}

Penyuluhan dan pelatihan pembuatan wedang jahe serai dalam rangka meningkatkan imunitas memberikan hasil yang baik, terlihat dengan meningkatnya pengetahuan responden dan antusiasme responden selama kegiatan.

\section{DAFTAR PUSTAKA}

Hendrik G, W., Erwin dan Panggabean, A. S. (2013). Pemanfaatan Tumbuhan Serai Wangi (Cymbopogon nardus (L.) RENDLE) Sebagai Antioksidan Alami. Jurnal Kimia Mulawarman, 10(2), 74-79.

Kemenkes RI. (2020). Pedoman Pencegahan Dan Pengendalian Coronavirus Disease (COVID-19). Revisi ke-5. Kementrian Kesehatan Republik Indonesia.

Melawati, D., Sudarsono dan Yuswanto, A. (2010). Pengaruh Pemberian Ekstrak Zat Pedas Rimpang Jahe Emprit yang Disari dengan Etanol 70\% Terhadap Fagositosis Makrofag Pada Mencit Jantan yang Diinfeksi 
dengan Listeria monocytogenes. Majalah Obat Tradisional, 15(3), 112120.

Mindarti, S., dan Nurbaeti, B. (2015). Buku Saku Tanaman Obat Keluarga (TOGA). Balai Pengkajian Teknologi Pertanian Jawa Barat.

Setiati, S. dan Azwar, M.K. (2020). COVID-19 and Indonesia. Acta Med IndonesIndones J Intern Med, 52(1), 84-89.

Tejasari., Zakaria, F.R., dan Sajuthi, D. (2002). Aktivitas Stimulasi Komponen Bioaktif Rimpang Jahe (Zingiber officinale Roscoe) Pada Sel Limfosit B Manusia Secara In Vitro. Jurnal Teknol dan Industri Pangan, XIII(1), 4753. 